\title{
ОСОБЛИВОСТІ ПІДГОТОВКИ ДО ЗДІЙСНЕННЯ ДОПИТУ ІНОЗЕМЦІВ
}

Кудінов С. С.

у статті на підставі аналізу чинного законодавства, спеціальної літератури та слідчо-судової практики визначені особливості підготовки до проведення допиту іноземців для створення оптимальних тактичних умов для одержання від них показань. Визначено, що під час формування змісту та послідовності питань у плані допиту іноземця мають бути враховані особливості його соціально-психологічної характеристики, рівень інтелекту й освіти, культурні та національні особливості, обставини й мета прибуття в Україну, законність підстав і термінів перебування в нашій державі, наявність у нього спеціальних знань, можливості спілкування українською мовою, обставин, за яких іноземець став учасником кримінальних процесуальних правовідносин, особливостей сприйняття іноземцем самого кримінального правопорушення, що розслідується. Визначені особливості підшукання перекладача, його перевірки і рівня підготовки для здійснення перекладу у кримінальному провадженні, виклику іноземця, підготовки до встановлення психологічного контакту з іноземцем. Сформульовані рекомендації щодо дій у ситуації наявності в особи імунітету від кримінальної юрисдикції України і небажання цієї особи (або держави, яку вона представляє) брати участь у кримінальному провадженні в Україні.

Ключові слова: допит, підготовка до допиту, іноземець, процесуальний статус, імунітет від кримінальноі юрисдикції.

B cтатье на основе анализа действующего законодательства, специальной литературы и следственно-судебной практики определены особенности подготовки к проведению допроса иностранцев для создания оптимальных тактических условий для получения от них показаний. Определено, что при формировании содержания и последовательности вопросов в плане допроса иностранца должны быть учтены особенности его социально-психологической характеристики, уровень интеллекта и образования, культурные и национальные особенности, обстоятельства и цель прибытия в Украину, законность оснований и сроков пребывания в нашем государстве, наличие у него специальных знаний, возможности общения на украинском языке, обстоятельств, при которых иностранец стал участником уголовных процессуальных правоотношений, особенностей восприятия иностранцем уголовного правонарушения, которое расследуется. Определены особенности поиска переводчика, его проверки и уровня подготовки для осуществления перевода в уголовном производстве, вызова иностранца, подготовки к установлению психологического контакта с иностранцем. Сформулированы рекомендации по действиям в ситуации наличия у лица иммунитета от уголовной юрисдикции Украины и нежелания этого лица (или государства, которое оно представляет) участвовать в уголовном производстве в Украине.

Ключевые слова: допрос, подготовка к допросу, иностранец, процессуальный статус, иммунитет от уголовной юрисдикции.

Кудінов С. С., 2019
In the article on the basis of the analysis of the current legislation, special literature and investigative-judicial practice, defined the peculiarities of preparation for the examination of foreigners in order to create optimal tactical conditions for obtaining testimony from them. It is determined that the content and sequence of questions in terms of examination of a foreigner should take into account the peculiarities of his socio-psychological characteristics, level of intelligence and education, cultural and national characteristics, circumstances and purpose of arrival in Ukraine, the legality of the grounds and terms of stay in our country, availability he has special knowledge, the ability to communicate in Ukrainian, the circumstances in which the foreigner became a party to criminal legal relations, the peculiarities of the foreigner's perception of the criminal of the offense under investigation. The features of the translator's search, their checking and the level of preparation for translating in criminal proceedings, calling a foreigner, preparing to establish psychological contact with a foreigner are determined. It is stated that in accordance with Part 4 of Art. 65 of the CPC of Ukraine, if a foreigner has the right of diplomatic immunity, then he or she must be given the consent to be questioned as a witness, and if he / she is an employee of the diplomatic mission, the consent of the representative of the diplomatic establishment must be obtained. Such consent must be obtained in writing from the foreigner and from the diplomatic mission in advance or immediately before the examination begins. Ignoring the need for such consent from investigators makes it impossible to question such foreigners.

Recommendations have been formulated to act in the event of a person having immunity from the criminal jurisdiction of Ukraine and the unwillingness of that person (or the state he or she represents) to participate in criminal proceedings in Ukraine. It is stated that the information known to this person can be recorded from the words in the form of a report of the investigator, in which the latter can outline the content of his conversation with a representative of a foreign state. These questions may also be questioned as witnesses by those present during the conversation (a law enforcement official, a translator, and representatives of the Ministry of Foreign Affairs of Ukraine).

Key words: examination, preparation for examination, foreigner, procedural status, immunity from criminal jurisdiction.

Постановка проблеми. Одним із напрямів, за якими відбувається формування сприйняття України як правової держави на міжнародному рівні, $\epsilon$ дотримання прав та свобод іноземців у кримінальних провадженнях, і не тільки у взаємозв'язку з особливостями їхнього правового статусу, але і з урахуванням соціально-психологічної складової частини та притаманної іноземним громадянам необізнаності про особливості здійснення досудового розслідування кримінальних правопорушень у нашій державі й, зокрема, проведення окремих процесуальних дій. Із числа процесуальних дій допит $\epsilon$ найбільш розповсюдженою слідчою (розшуковою) дією. У слідчій практиці кількість допитів іноземців, особливо тих, що володіють дипломатичним або 
іншими видами імунітету від кримінальної юрисдикції України, є незначною. На цьому фоні відсутність наукових рекомендацій щодо здійснення допитів таких осіб на підставі нормативних приписів КПК України 2012 року створює передумови як для порушення положень вітчизняного, міжнародного законодавства, так і ускладнень на дипломатичному рівні.

Аналіз останніх досліджень і публікацій. Розуміння важливості розроблення питань здійснення досудового розслідування кримінальних правопорушень, вчинених іноземцями або відносно іноземців, спонукало Д.О. Алєксєєву-Процюк, Р.В. Баранніка, О.І. Бастрикіна, Р.С. Бєлкіна, П.Н. Бірюкова, О.М. Бриськовську, Н.О. Жукову, О.А. Калганову, І.М. Князєва, І.І. Когутича, А.Г. Крамарева, В.П. Лаврова, П.Г. Назаренка, О.І. Олександрової, К.Є. Остроги, Л.Д. Удалову, Л.Г. Шарай та інших до здійснення їх дослідження. Завдяки цьому опрацьовані питання впливу правового статусу іноземців на проведення процесуальних дій за їх участі, залучення перекладачів та пов'язана із цим специфіка тактики проведення допиту такої категорії осіб.

Виділення не вирішених раніше частин загальної проблеми. Однак поза рамками наявних робіт залишаються особливості підготовки до здійснення допиту іноземців з урахуванням положень КПК України 2012 року.

Метою статті $\epsilon$ визначення на підставі аналізу чинного законодавства, спеціальної літератури та слідчо-судової практики особливостей організації проведення допиту іноземців для створення оптимальних тактичних умов для одержання від них показань.

Виклад основного матеріалу. Особливості здійснення розслідування у кримінальних провадженнях щодо кримінальних правопорушень, вчинених іноземцями, за їх участі або відносно іноземців науковці і практичні працівники пов'язують, насамперед, з окремими властивостями особи іноземця як специфічного учасника кримінального процесу.

Готуючись до проведення допиту іноземця, слідчий повинен з особливою ретельністю вивчити матеріали кримінального провадження, відомості щодо особи іноземця, його соціально-психологічної характеристики, рівня інтелекту й освіти, схильностей, способу життя, характеру, обставин і мети прибуття в Україну, законності підстав і термінів перебування в нашій державі, наявності в нього спеціальних знань, можливості спілкування українською мовою, обставин, за яких іноземець став учасником кримінальних процесуальних правовідносин, особливостей сприйняття іноземцем самого кримінального правопорушення, що розслідується. Це дасть змогу слідчому правильно й вичерпно визначити предмет допиту, а потім у плані допиту - зміст та логічну послідовність питань, які будуть ставитися допитуваному. Роботу щодо визначення кола питань, які підлягають встановленню під час допиту іноземця, потрібно проводити особливо ретельно. Як правило, повторний допит іноземця часто організаційно ускладнений або неможливий у зв'язку з тим, що іноземець у короткий термін може виїхати за межі України. Визначаючи коло питань, на які буде запропоновано відповісти іноземцю, треба звернути увагу не тільки на їх зміст, тактичне значення, але й на те, що ці питання можуть бути сприйняті допитуваним як політично й ідеологічно спрямовані. Краще уникати постановки перед іноземцем питань щодо його політичних переконань або національних почуттів. О.М. Брисковська та Д.О. Алєксєєва-Процюк вірно вказують, що іноземець може бути упереджений із приводу наявного в нашій країні режиму влади, мати перекручені уявлення про права та обов'язки українських громадян, процесуальний порядок їх обмеження і т. д. [1, с. 108]. Дійсно, такі питання можуть перетворити допит або іншу слідчу (розшукову) дію на дискусію про політику, ідеологію або національні відносини. Проте в окремих випадках знання слідчим особистої позиції допитуваних із зазначених проблемних питань може мати значення для встановлення психологічного контакту з особою. І тому з'ясування таких обставин можна віднести до підготовки слідчого до допиту. Це можна здійснити шляхом попереднього допиту інших осіб, які знають іноземця, вивчення документів та інших матеріалів кримінального провадження. Доречним буде звернення за допомогою до оперативних працівників, які можуть надати слідчому за наявності інформацію щодо особистих уподобань іноземця. У таких випадках навіть немає потреби в розкритті джерела оперативної інформації, оскільки вона буде використана слідчим не як докази, а для обрання тактичних прийомів проведення конкретної слідчої (розшукової) дії.

Також слідчому слід мати хоча б загальні знання щодо країни, де мешкає іноземець, або громадянином якої він $€$, національних традицій, населення, наявності міжнаціональної ворожнечі на батьківщині іноземця, тощо. Так, наприклад, можуть виникнути труднощі щодо встановлення особи жінки-мусульманки, якій за національними традиціями заборонено відкривати обличчя перед сторонніми особами чоловічої статі, в тому числі й перед слідчим. У такому випадку питання встановлення особи такої жінки можна вирішити шляхом залучення слідчого жінки.

Слід обмірковувати не тільки зміст питань, але й форму їх постановки. Питання, звернені до іноземця, повинні бути виключно конкретними й тактовними. Також треба звернути увагу на лексику й стиль мовлення під час формулювання питань. Одне й те ж саме слово особами різної соціальної, національної та державної належності може бути сприйнято іноді з різним смисловим значенням.

Для підвищення ефективності підготовки слідчого до проведення слідчих (розшукових) дій за участі іноземців можна залучати спеціалістів, до того ж фах спеціалістів може бути не пов'язаним із предметом допиту. Наприклад, це викладачі навчальних закладів, де навчаються іноземці, особи, що були за кордоном у тій місцевості або державі, звідки походить іноземець, фахівці у сфері іноземних культур та традицій, особи, яким можуть бути відомі дані щодо обставин життя іноземця та формування його правосвідомості, шляху прибуття в Україну та інше. У кожному конкретному випадку питання необхідності залучення до участі в допиті певних фахівців вирішується окремо з урахуванням обставини кримінального провадження. До етапу підготовки слід віднести й перевірку наявності перешкод щодо можливості допиту іноземця з окремих обставин, які мають значення для кримінального провадження. Наприклад, для свідка щодо вчинення кримінального правопорушення його родичем (п. 3 ч. 1 ст. 66 КПК України), відомостей, які згідно з положеннями статті 65 КПК України не підлягають розголошенню або наявних 
на батьківщині іноземця заборон (державної таємниці, релігійних «табу» тощо).

Відповідно до п. 4 ч. 1 ст. 52 КПК України обов'язковою $\epsilon$ участь захисника у випадках коли особа не володіє мовою, якою ведеться кримінальне провадження - з моменту встановлення цього факту. Іноді слідчі не приділяють цьому достатньої уваги, зокрема, у випадках притягнення до кримінальної відповідальності громадян із країн колишнього СРСР, вважаючи, що вони добре розуміють чи повинні розуміти українську або російську мову. Слідчий і підозрюваний добре розуміють один одного, але слідчий складає документи українською мовою, а іноземець ії не розуміє, і йому поряд із перекладачем необхідно надати ще й захисника, в іншому випадку це буде порушенням закону.

До підготовчих дій слід віднести також і попереднє опрацювання матеріалів кримінального провадження, які слідчий планує використовувати під час проведення допиту іноземця шляхом їх пред'явлення: протоколи слідчих (розшукових) дій, документи, матеріли відео-, аудіозапису, висновки експертів тощо. Особливістю такого опрацювання $\epsilon$ те, що вони потребують перекладу на іноземну мову, іноді це вимагає роз'яснення іноземцю обставин їх отримання, фактів, які засвідчують зазначені документи.

Питання пошуку перекладача $\epsilon$ не менш важливим у зв'язку з тим, що зазвичай іноземці не в достатньому обсязі володіють українською та російською мовами, а іноді володіють такими різновидами іноземних мов та діалектів, які не часто трапляються серед іноземців, щомешкають уконкретномурегіоніабов Україні загалом.

Питання підбору перекладачів рекомендується вирішувати шляхом пошуку останніх через Довідково-інформаційний реєстр перекладачів, володільцем якого $\epsilon$ Державна міграційна служба України [2]. Рада суддів України у своєму рішенні № 48 від 09.06.2016 «Про залучення перекладачів у кримінальному провадженні» зазначає, що в Реєстрі перекладачів не завжди $є$ інформація про перекладача, який володіє і розуміє ту мову, якою володіє чи розуміє та особа, для якої необхідно залучити такого перекладача, особливо це викликає труднощі під час пошуку перекладача з мови, яку не викладають у школах чи закладах вищої освіти. Крім того, 3 наявної інформації в Реєстрі перекладачів неможливо визначити відповідність перекладача критеріям фахівця, а саме, чи достатній він має рівень розуміння тієї чи іншої мови, виходячи зі специфіки юридичної термінології, що має важливе значення під час здійснення кваліфікованого перекладу [3]. Тому слідчому рекомендується звертатися із запитом до Реєстру перекладачів і паралельно до адміністрації шкіл, вищих навчальних закладів, у яких викладається мова, переклад з якої потрібен у кримінальному провадженні, а також до бюро перекладів. У випадках, коли перекладачів із числа викладачів закладів освіти або співробітників бюро перекладів немає, можна звернутися до керівника дипломатичного представництва держави, у якій мова, з якої необхідно здійснити переклад, $є$ державною, щодо можливості залучення в якості перекладача співробітника дипломатичного представництва або надання інформації щодо відомих дипломатичному представництву осіб, які можуть здійснити переклад у кримінальному провадженні та знаходяться на території України. Також щодо необхідного у кримінальному провадженні перекладача можна звертатися до туристичних агенцій, представництв іноземних компаній, Торговельно-промислові палати України, іноземних діаспор в Україні, МЗС України. У випадках залучення таких перекладачів слід обов'язково вивчати питання щодо можливої упередженості цих осіб. Таку перевірку рекомендується проводити у взаємодії із працівниками оперативних підрозділів.

У практиці мають місце непоодинокі випадки завідомо неправдивих перекладів, які перекручують обставини події і ускладнюють процес розслідування кримінального правопорушення, що може робитися на прохання родичів чи друзів іноземця, представників іноземної держави з метою приховати певні факти або обставини, що їх компрометують, або з метою введення в оману слідчого. Іноді самі іноземці заявляють клопотання щодо виклику лише певних осіб у якості перекладачів. Треба виважено підходити до питання розв'язання таких клопотань та перед прийняттям відповідного процесуального рішення з'ясувати причини та потребу запрошення саме таких осіб, перевірити їх незацікавленість у результатах досудового розслідування і тоді лише вирішувати питання позитивно. Не існує заперечень і щодо участі у слідчій дії двох перекладачів - підібраного слідчим та запрошеного допитуваним. Насамперед це стосується тих випадків, коли переклад здійснюється зі складних, рідкісних мов, і сам перекладач погано володіє однією з мов, що використовуються під час допиту. Наприклад, запрошений до участі у справі перекладач $\epsilon$ афганцем за походженням і добре володіє своєю рідною мовою, а українською мовою і юридичною термінологією володіє погано і тому йому складно перекладати. У якості другого перекладача доцільно залучити, особу, що освічена в юриспруденції, вільно володіє українською мовою і може розуміти афганську мову.

Крім того, слідчому під час пошуку перекладача особливу увагу слід звернути на встановлення існування можливих особливостей мовлення іноземців - учасників слідчої (розшукової) дії, та перекладача, наявність діалектів (різновидів) окремих іноземних мов.

Також до підготовчих заходів, які необхідно враховувати під час організації як окремої слідчої (розшукової) дії, так і розслідування кримінального правопорушення, в цілому варто віднести питання доставки перекладача до місця проведення слідчої (розшукової) дії. Це пов'язано з доставкою перекладача до місця, де знаходиться орган досудового розслідування, утримуються затримані іноземці, - ізолятор тимчасового утримання, приймальник-розподільник, слідчий ізолятор. Іноді це також може бути пов'язано і доставкою перекладача в місце, де буде проводитися слідча (розшукова) дія, наприклад слідчий експеримент. Така доставка передбачає вжиття слідчим певних організаційних заходів: пошук транспорту, оплата перекладачу проїзду до місця проведення слідчої (розшукової) дії.

Під час розслідування кримінальних правопорушень, пов'язаних із участю іноземців, вступати в контакти з іноземними громадянами і викликати останніх для проведення слідчих (розшукових) дій доцільно через відповідні державні або недержавні органи і громадські організації, за запрошенням чи дозволом яких іноземець прибув в Україну і які мають із ним ділові стосунки. Час і місце допиту визначаються з урахуван- 
ням часу перебування і місця знаходження іноземця в Україні.

Виклик для участі у проведенні слідчих (розшукових) дій іноземців, які прибули у країну у складі делегацій, туристичних груп, морських круїзів і т. ін., необхідно здійснювати через керівників цих груп, делегацій. Учні або студенти можуть бути викликані через адміністрацію навчальних закладів, земляцтва й інші організації, до яких вони входять. Особи, що перебувають в Україні на постійній основі - фахівці і робітники, можуть бути викликані через адміністрацію фірм і установ. При цьому слідчий повинен обміркувати, як іноземець, що не знає мови і міста, зможе знайти правоохоронний орган й місце проведення слідчої (розшукової) дії.

Відповідно до ч. 4 ст. 65 КПК України якщо іноземець має право дипломатичної недоторканності, то від нього має бути одержана згода на допит його в якості свідка, а якщо він $є$ працівником дипломатичного представництва - то має бути одержана згода представника дипломатичної установи. Така згода має бути одержана в письмовій формі від іноземця та від дипломатичного представництва заздалегідь або безпосередньо перед початком допиту. Ігнорування слідчим необхідності одержати таку згоду унеможливлює проведення допиту таких іноземців.

Висновки. Слід значити, що розглянуті особливості підготовки слідчого до допиту іноземця, зокрема визначення змісту та послідовності питань у плані допиту, підшукання перекладача, його перевірка і підготовка, виклик іноземця, підготовки до встановлення психологічного контакту з іноземцем - $\epsilon$ загальними особливостями, що характерні для організації і проведення майже всіх слідчих (розшукових) дій з іноземцями за кримінальними провадженнями про будь-які кримінальні правопорушення.

У разі наявності в особи імунітету від кримінальної юрисдикції України і небажання цієї особи (або держави, яку вона представляє) брати участь у кримінальному провадженні в Україні, інформація, яка відома цій особі, може бути зафіксована зі слів у вигляді рапорту слідчого, у якому останній може викласти зміст його бесіди із представником іноземної держави. Із цих питань також можуть бути допитані в якості свідків особи, що були присутні під час цієї розмови (наприклад, представник правоохоронного органу, перекладач, представники МЗС України).

\section{Література}

1. Брисковська О.М., Алєксєєва-Процюк Д.О. Тактика проведення процесуальних дій з іноземцями при розслідуванні незаконного переправлення осіб через державний кордон. Право.иа. 2017. № 2. С. 105-110.

2. Реєстр перекладачів. Державна міграційна служба України. URL : https://dmsu.gov.ua/services/ translates.html.

3. Рішення Ради суддів України № 48 від 09.06.2016 «Про залучення перекладачів у кримінальному провадженні». URL : http://www.rsu.gov.ua/ua/events/risenna-rsu-no-48vid-09062016-pro-zalucenna-perekladaciv-u-kriminalnomuprovadzenni.

Кудінов С. С., доктор юридичних наук, доцент, ректор Національної академії Служби безпеки України 